\title{
Multienzymic Effect with Prebiotics and Probiotics on Carcass Characteristics of Broilers
}

\author{
Harshavardhan Shahaji Sonawane ${ }^{1 *}$, Mahendra Mohan Yadav², \\ Ghoshita S. Hingonekar ${ }^{1}$, Dhiraj H. Kankhare ${ }^{1}$ and Vipul M. Vasave ${ }^{1}$ \\ ${ }^{1}$ Department of Animal Husbandry and Dairy Science, College of Agriculture, Dhule, India \\ ${ }^{2}$ Department of Animal Husbandry and Dairy Science, RCSM College of Agriculture, \\ Kolhapur, Mahatma Phule Krishi Vidyapeeth, Rahuri, Maharashtra, India \\ *Corresponding author
}

\section{A B S T R A C T}

\begin{tabular}{l} 
K e y w o r d s \\
$\begin{array}{l}\text { Broilers, Carcass } \\
\text { characteristics, } \\
\text { Enzymes, Prebiotics } \\
\text { Probiotics }\end{array}$ \\
\hline Article Info \\
$\begin{array}{l}\text { Accepted: } \\
\text { 12 December } 2020 \\
\text { Available Online: } \\
\text { 10 January } 2021\end{array}$ \\
\hline
\end{tabular}

Keywords

Broilers, Carcass characteristics, Enzymes, Prebiotics Probiotics

\section{Introduction}

Poultry industry is one of the fastest growing segments of Indian economy. The Indian poultry market, consisting of broilers and eggs was worth INR 1,750 Billions in 2018 (Source: Internet). India today is the one of the world's largest producer of eggs and broiler meat. The poultry industry in India has undergone a major shift in structure and operation during the last some decades transforming from a mere backyard activity of rural farmers into a major industry with the presence of a large number of integrated players.

Different types of feed additives like antibiotics, steroids, vitamins, minerals and other growth promoters are being used to improve the performance of broiler growth. The excessive dependency on medications threatens the mankind in antibiotic resistance. 
Probiotics are feed additives that contain live microorganisms and promote beneficial effects on the host of favouring the balance of the intestinal microbes (Fuller, 1989).

Broiler meat in the past had been considered to be a delicacy. Now a day it is vital food stuff according to health benefits. It also develops immunity in the human being to fight against COVID-19 virus situation; also it is increasingly seen as less of a luxury product and more as a daily staple diet.

The share of poultry in domestic meat production has grown swiftly. By 2006, India was producing 2.0 million metric tons of poultry-meat (Hellin and Erenstein, 2009) and presently producing approximately 3.6 million metric tons (DAHD, 2016-17). The per-capita consumption of meat is expected to increase in India, from its current level of 3.1 $\mathrm{kg}$ to $18 \mathrm{~kg}$ by 2050 , of which $12.5 \mathrm{~kg}$ would be chicken (Alexandratos and Bruinsma, 2012). Increasing demand for Poultry meat is justified by its wide acceptability and rich taste, high protein content, low fat content and comparatively economical than other meat products without disparity among regions and religions (Manning and Baines, 2004). Currently, consumers around the world are increasingly more conscious of the nutritional value and safety of their food and its ingredients. In India, the main human nutritional problem is the food shortage that cannot meet the increasing population.

\section{Materials and Methods}

The present research was conducted at Division of Animal Husbandry and Dairy Science, College of Agriculture, Dhule, Maharashtra, India located at $20.90020 \mathrm{~N}$ and $74.79880 \mathrm{E}$ at an altitude of 258 meter. Minimum and maximum ambient temperature range from $10^{\circ} \mathrm{C}$ to $15^{\circ} \mathrm{C}$ in winter and $35^{\circ} \mathrm{C}$ to $40^{\circ} \mathrm{C}$ in summer with annual rainfall of 612 $\mathrm{mm}$. The experiment was conducted in March - April during the year 2019-20. All the experimental chicks were reared in deep litter system with use of paddy husk as a litter material in a well-ventilated house with identical management and environmental conditions. Proper brooding of chicks was done by providing sufficient heat and light by using electric bulbs in each group for first three weeks of age.

Enzymes having trade name BR Enzypro (Cocktail Enzyme) was procured from Brisk Bioscience, Surat (Gujarat) Commercial seller and mixed in commercial broiler feed manufactured by Godrej industries as per different treatment levels and mixed with constant dose of Prebiotics $(0.5 \%)$ and Probiotics $(0.1 \%)$.

\section{Selection of experimental chicks}

For the present study 120 chicks of day old age, commercial straight run broiler chicks of Vencob strain were procured from Government approved hatchery near to Dhule, Maharashtra. On arrival, chicks were weighed and distributed randomly into 4 treatment groups viz, $\mathrm{T}_{0}, \mathrm{~T}_{1}, \mathrm{~T}_{2}$, and $\mathrm{T}_{3}$ with 30 chicks in each treatment, on equal weight basis.

\section{Treatment details}

The dietary treatments are as follows,

$\mathrm{T}_{0}$ - Control [Basal Diet + Prebiotics (0.5g per $1 \mathrm{~kg}$ mash) and Probiotics $(0.1 \mathrm{~g}$ per $1 \mathrm{~kg}$ mash)]

$\mathrm{T}_{1}$ - Basal Diet + Prebiotics $(0.5 \mathrm{~g}$ per $1 \mathrm{~kg}$ mash) and Probiotics (0.1g per $1 \mathrm{~kg}$ mash) + Multi-enzyme (0.1\% of mash)

$\mathrm{T}_{2}$ - Basal Diet + Prebiotics $(0.5 \mathrm{~g}$ per $1 \mathrm{~kg}$ mash) and Probiotics (0.1g per $1 \mathrm{~kg}$ mash) + 
Multi-enzyme ( $0.2 \%$ of mash)

$\mathrm{T}_{3}$ - Basal Diet + Prebiotics $(0.5 \mathrm{~g}$ per $1 \mathrm{~kg}$ mash) and Probiotics (0.1g per $1 \mathrm{~kg}$ mash $)+$ Multi-enzyme ( $0.3 \%$ of mash)

\section{Proximate composition of experimental broiler ration}

It was observed that experimental broiler rations contained adequate nutrients for growth as per BIS (1992). The proximate composition of experimental starter ration and finisher ration is given in Table 1 . The crude protein and calculated metabolizable energy (ME) of the starter diet was 22.9 per cent and $2863.83 \mathrm{Kcal} / \mathrm{kg}$, respectively. Whereas crude protein and calculated metabolizable energy (ME) of finisher diet was 20.0 per cent and $2939.78 \mathrm{Kcal} / \mathrm{kg}$, respectively.

\section{Observations recorded}

\section{Body weight}

The weight $(\mathrm{g})$ of the all experimental birds was recorded individually on electronic weighing balance at weekly intervals. The weights were recorded on $7^{\text {th }}$ day morning before offering fresh water and feed and subsequently at 7 days interval. Live weight gains were calculated by subtracting live weight of previous week from that of current week.

\section{Carcass traits}

Carcass traits were evaluated after slaughtering, dressing and evisceration of birds. Three birds from each treatment were used for carcass traits evaluation. Live weight was recorded prior to slaughter of birds. The birds were slaughtered by standard protocol and allowed to bleed for 180 seconds, in bleeding cones. The birds were then reweighed to record the bleed weight.
Scalding was done at $62^{\circ} \mathrm{C}$ for 120 seconds and feathers were removed manually. The birds were then reweighed to record the defeathered weight. The birds were then processed by removing the skin, head, shank, feet and preen glands were eviscerated by cutting around vent and removing the viscera. The giblets consisting of heart (without pericardium), liver (without gall bladder) and gizzard were cut open and rinsed of its contents. All of the above components and eviscerated carcass were weighed individually.

The neck was removed from carcass and wings were removed by a cut through the shoulder joint at the proximal end of humorus. The thigh-drumstick portion was obtaining by cutting through the joint between femur and the ilium bone of pelvic girdle. The drumstick was then separated from the thigh by a cut through the joint formed by the femur and fibula and tibia.

The breast and the back portions were obtained by cutting on each side of the vertebral column beginning at the midpoint of the sternal ribs until the breast portion completely removed from the back .The cutting procedure resulted in two wings, two drumsticks, two thighs, one breast and one back part. Individual weight of various vital organs like heart, liver, and gizzard were recorded after removal of contents present in gizzard and detachment of gall bladder from liver.

\section{Statistical analysis}

The data were analysed using General Linear Model procedure of statistical package for social sciences (SPSS) and comparison of means tested using Duncan's multiple range test (1997) and significance was considered at $(\mathrm{P}<0.05)$. 


\section{Results and Discussion}

Present study was conducted to investigate the combined effects of multi-enzymes, probiotic and prebiotic on broilers performance and carcass characteristics. Table 2 represents the data on carcass traits (\%) due to different dietary treatments of Multi-enzymes with constant level of Prebiotics and Probiotics supplementation during experimental period. The data also presented graphically in Fig. 1.

The carcass characteristics data indicated significant difference in the carcass traits (\%) among treatment groups. The breast yield was highest in the treatment $\mathrm{T}_{3}(34.78 \mathrm{~g})$ group whereas $\mathrm{T}_{2}(33.84 \mathrm{~g}), \mathrm{T}_{1}(32.56 \mathrm{~g})$ and $\mathrm{T}_{0}$ $(31.56 \mathrm{~g})$. It was clear that there was a difference in $T_{3}, T_{2}$ and $T_{1}$ over control $T_{0}$. Although a slight variation was observed in drumstick and thigh per cent of the carcass weight of different treatment groups, it was statistically significant. Giblet per cent of the carcass weight was slightly higher in $T_{1}$ as compared to $T_{3}$ and $T_{2}$ and had more when compared to control group. These results are consistent with Selle et al., (2003) who found that supplementation of wheat based diets with xylanase plus phytase increased breast weight by 5.8 per cent. Similar results were also observed by Kabir et al., (2004) who reported supplementation of probiotics to broiler chickens increased thigh and breast yield as compared to control treatment. This result was in agreements with findings of Wang et al., (2015), who reported that the addition of the prebiotic @ 0.13 per cent resulted in lowest eviscerated carcass ratio of broilers and also lower live weight than other group of broilers. Anjum et al., (2005) showed differences in feed intake, meat composition, dressing percentage and empty organ weights among all the diets supplemented with multi-strain probiotic (protexin) were non-significant. However, abdominal fat content was reduced significantly $\quad(\mathrm{P}<0.05) \quad$ in $\quad$ supplemented groups. Mehr et al., (2007) observed higher body and carcass weights and breast percentage with higher level of probiotic supplementation compared with a lower level and the control treatment. Boostani et al., (2013) showed that the highest $(p \leq 0.05)$ carcass and thigh values were recorded for broilers fed the diet supplemented with thepax and yogurt, respectively.

Our results were contradictory with Ceslovas et al., (2005), who observed that probiotic supplementation significantly $\quad(\mathrm{P} \leq 0.05)$ increased the meat tenderness and meat quality. Most of the carcass characteristics are directly proportional to the increased body weight at the time of slaughter. Rabieet al., (2010) concluded that no significant effect on carcass traits of broiler chicks when supplemented with either probiotic (Avian plus: at $150 \mathrm{~g} / \mathrm{ton}$ diet), an enzyme preparation (Sicozyme: at $500 \mathrm{~g} / \mathrm{ton}$ diet), or their combination. Pourakbari et al., (2016) demonstrated there were no effects on carcass traits, but the relative weights of drumsticks and wings showed increasing and decreasing linear responses, respectively, to probiotic supplementation level. Sarangi et al., (2016) showed that there was no significant $(p>0.05)$ difference in the carcass traits with respect to dressing percentage, carcass percentage, heart weight, liver weight and gizzard weight, wing percentage, breast percentage, back percentage, thigh percentage, and drumstick percentage in Cobb broilers by the dietary inclusion of prebiotic, probiotic, and synbiotic compared with unsupplemented control in a commercial broiler chicken. Balamurugan (2004) observed no significant difference in dressing percentage of broilers fed with corn soya based diet supplemented Enzymes. No significant difference in the weight of giblets due to supplementation of NSP degrading Enzymes alone or in combination with 
phytase to corn soya based broiler diet. Zakaria et al., (2010) studied that Carcass characteristics showed no significant effects on whole carcass weight and/or dressing percent and weight and percent of breast, thighs and wings. Enzyme supplemented diets significantly $(\mathrm{p}<0.05)$ increased liver percent in contrast to Con diet, while no significant differences were reported for heart, gizzard and abdominal fat pad. The addition of enzyme did not significantly impact meat quality traits ( $\mathrm{pH}$, cooking loss, water holding capacity, shear force and colour attributes). However, comparison is difficult because of different management conditions, different combinations used in the various studies and different geoclimatic conditions.
There is likelihood that enhanced metabolism has valuable impact on weight gain in multienzyme, prebiotic and probiotics treated groups as compared to control group. The enhanced in weight gain of broiler chickens in $\mathrm{T}_{3}$ group as observed in the present study may be attributed to the fact that the digestibility of crude protein and energy present in the form of non-starch polysaccharides (NSPs) might have increased thus increasing availability to the birds for utilization and overall enhancement of body weight and this could also be due to control of pathogenic bacteria and modulation of intestinal morphology and expression of mucin and brush border enzyme.

Table.1 Proximate chemical composition of experimental broiler ration (\% DM basis)

\begin{tabular}{|c|c|c|}
\hline \multirow{2}{*}{ Nutrients } & Starter & Broiler ration \\
\cline { 2 - 3 } & 23.10 & Finisher \\
\hline Crude protein & 4.63 & 20.13 \\
\hline Crude fiber & 4.80 & 3.79 \\
\hline Ether extract & 7.20 & 4.30 \\
\hline Total ash & 60.40 & 6.85 \\
\hline Nitrogen free extract & 1.25 & 65.15 \\
\hline Acid insoluble ash & 2863.83 & 1.44 \\
\hline ME (Kcal/kg) & & 2939.78 \\
\hline
\end{tabular}

Table.2 Effect of supplementation of Multienzymes constant levels of Prebiotics and Probiotics on carcass traits of broilers

\begin{tabular}{|c|c|c|c|c|c|c|}
\hline \multirow{2}{*}{$\begin{array}{c}\text { Carcass traits } \\
(\%)\end{array}$} & \multicolumn{4}{|c|}{ Treatments } & \multirow{2}{*}{$\underset{( \pm)}{\operatorname{Mean} S E}$} & \multirow[t]{2}{*}{ CD@ $@ 5 \%$} \\
\hline & T0 & T1 & T2 & T3 & & \\
\hline $\begin{array}{l}\text { Live body } \\
\text { weight }\end{array}$ & $1,954.33^{\mathrm{d}}$ & $1966.17^{\mathrm{c}}$ & $1976.33^{b}$ & $2000.67^{\mathrm{a}}$ & 0.98 & 2.91 \\
\hline Breast (\%) & $31.56^{\mathrm{b}}$ & $32.56^{\mathrm{b}}$ & $33.84^{\mathrm{a}}$ & $34.78^{\mathrm{a}}$ & 0.36 & 1.07 \\
\hline Giblet (\%) & $4.62^{c}$ & $5.64^{\mathrm{a}}$ & $4.99^{\mathrm{bc}}$ & $5.32^{\mathrm{ab}}$ & 0.20 & 0.58 \\
\hline Drumstick (\%) & $11.33^{b}$ & $11.54^{\mathrm{ab}}$ & $11.16^{\mathrm{b}}$ & $11.96^{\mathrm{a}}$ & 0.17 & 0.50 \\
\hline Thigh (\%) & $10.71^{\mathrm{b}}$ & $11.80^{\mathrm{a}}$ & $10.84^{b}$ & $11.84^{\mathrm{a}}$ & 0.26 & 0.77 \\
\hline Edible (\%) & $63.30^{b}$ & $64.89^{\mathrm{a}}$ & $64.94^{\mathrm{a}}$ & $65.56^{\mathrm{a}}$ & 0.26 & 0.79 \\
\hline Non-Edible (\%) & $36.00^{\mathrm{a}}$ & $35.60^{\mathrm{a}}$ & $35.39^{\mathrm{ab}}$ & $34.87^{b}$ & 0.24 & 0.73 \\
\hline Dressed Weight & $1261.69^{c}$ & $1292.55^{\mathrm{b}}$ & $1297.13^{b}$ & $1334.48^{\mathrm{a}}$ & 3.92 & 11.65 \\
\hline Dressing (\%) & $64.57^{\mathrm{c}}$ & $65.74^{\mathrm{b}}$ & $65.63^{b}$ & $66.70^{\mathrm{a}}$ & 0.22 & 0.66 \\
\hline
\end{tabular}




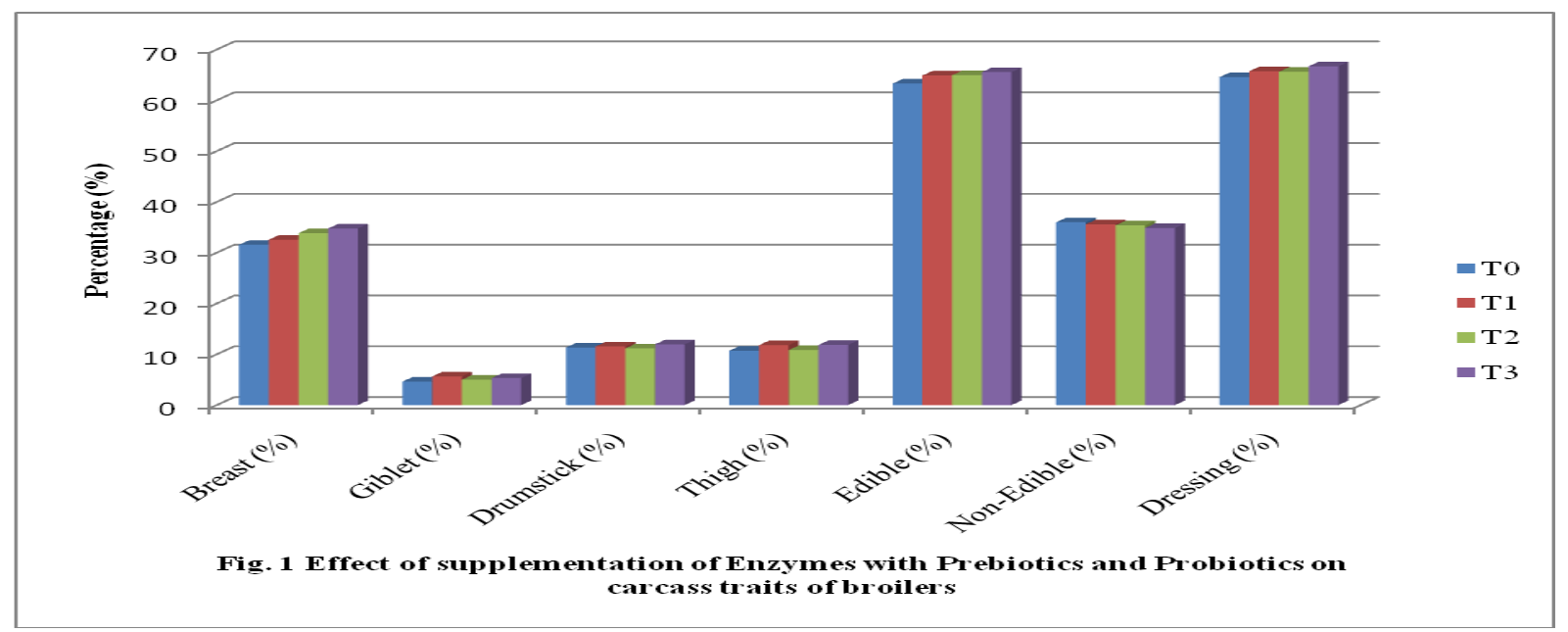

The enhanced body weight in the $\mathrm{T}_{3}$ group as compared to control and other treatment may be due to additive effect of Multienzymes with Prebiotics and Probiotics. Multienzyme supplementation enhances broiler performance by mechanism of converting non-starch polysaccharides to meat mass or improving nutrient digestibility and bioavailability of the nutrients.

In conclusion the supplementation of multienzymes @ 0.3 per cent with 0.5 per cent Prebiotics, 0.1 per cent Probiotics in the feed of broiler birds showed better results for the carcass characteristic having significant difference as compare to other treatments i.e. Multienzyme @ 0, 0.1 and 0.2 per cent with constant levels of Prebiotics (Fructooligosaccharides @ 0.05\%) and Probiotics (Saccharomyces cervisiae @ 0.01 $\%)$. The results of the present study showed that Probiotic plus Prebiotic and multienzyme supplementation significantly increased carcass weights in 42 days.

\section{References}

Alexandratos, N. and Bruinsma, J. (2012). World agriculture towards 2030/2050: the 2012 revision, ESA working paper no. 12-03.
Anjum, M. I., Khan, A. G., Azim, A. and Afzal, M. (2005).Effect of dietary supplementation of multi-strain probiotic on broiler growth performance.Pakistan Veterinary Journal, 25(1):25-29.

Anonymous: Indian poultry market report: (2019).

Balamurugan, R., (2004). Performance and intestinal response of broiler chickens fed on multi enzyme supplemented diet. M.V.Sc., thesis, submitted to Tamil Nadu Veterinary and Animal Sciences University, Chennai.

Boostani, A., Ashayerizadeh, A., MahmoodianFard, H. R., Aminafshar, M. (2013).Growth Performance, Carcass yield and Intestinal Microflora Populations of Broilers Fed Diets Containing Thepax and Yogurt. Brazilian Journal of Poultry Science.

Ceslovas, J., Junka, V. and Simkus, A. (2005).The effect of probiotics and phytobiotics on meat properties and quality in pigs. VeterinarijaIr Zootechnika T., 29(51): 1392-2130.

DAHD (Department of Animal Husbandry and Dairying) (India): report 2016-17.

FAO. (2008). Poultry in the 21st Century: Avian influenza and beyond. United Nations, Rome. 
Fuller R. (1989).Probiotics in man and animals.J. Appl. Bacterol., 66: 365-378.

Hellin, J. and Erenstein, Olaf. (2009). MaizePoultry Value Chains in India: Implications for Research and Development. Journal of New Seeds. 10: 245-263.

Kabir, S. M. L., Rahman, M. M., Rahman, M. B., Rahman, M. M., Ahmed, S. U. (2004). The dynamics of probiotics on growth performance and immune responsein broilers.International Journal of Poultry Science, 3:361-364.

Manning, L. and Baines, R. N. (2004).Effective management of food safety and quality.British Food Journal. 106: 598-606.

Mehr, M. A., Shargh, M. S., Dastar, B., Hassani, S. and Akbari, M. R. (2007). Effect of different levels of protein and Protexin on broiler performance. Int $J$ Poultry Sci 6: 573-577.

Pourakbari, M., Seidavi, A., Asadpour, L. and Martínez, A. (2016). Probiotic level effects on growth performance, carcass traits, blood Parameters, cecalmicrobiota, and immune response of broilers. Annals of the Brazilian Academy of Sciences, 88(2): 1011-1021.

Rabie, M. H., Ismail, F.S A. and Sherif, S. K. (2010).Effect of dietary energy level with probiotic and enzyme addition on performance, nutrient digestibility and carcass traits of broilerEgypt. Poult. Sci. 30 (I): 179-201.
Sarangi, N. R., Babu, L. K., Kumar, A., Pradhan, C. R., Pati, P. K., Mishra, J. P. (2016). Effect of dietary supplementation of prebiotic, probiotic, and synbiotic on growth performance and carcass characteristics of broiler chickens. Veterinary World, 9(3): 313319.

Selle, P. H., Ravidran, V., Ravidran, G., Pittolo, P. H. and Bryden, W. L. (2003). Effects of nutrient specifications and xylanase plus phytase supplementation of wheat-based diets on growth performance and carcass traits of broilers.Asian-australs J. Anim. Sci. 16: 1501-1509.

SPSS (1997).Release 8 for Windows.SPSS, Chicago, IL.

Wei Wang, Haiming Yang, Zhiyue Wang, Juan Han, Decai Zhang, Hongnuan Sun and Fenfen Zhang (2015) Effects of prebiotic supplementation on growth performance, slaughter performance, growth of internal organs and small intestine and serum biochemical parameters of broilers. Journal of Applied Animal Research, 43:1, 33-38.

Zakaria, A. H., Mohammad, A. R., Jalal and Majdi, A. Abu (2010). The influence of supplemental multi-enzyme feed additive on the performance, carcass characteristics and meat quality traits of broiler chickens. International Journal of Poultry Science 9(2): 126-133.

\section{How to cite this article:}

Harshavardhan Shahaji Sonawane, Mahendra Mohan Yadav, Ghoshita S. Hingonekar, Dhiraj H. Kankhare and Vipul M. Vasave. 2021. Multienzymic Effect with Prebiotics and Probiotics on Carcass Characteristics of Broilers. Int.J.Curr.Microbiol.App.Sci. 10(01): 927-933. doi: https://doi.org/10.20546/ijcmas.2021.1001.111 